\title{
Shaping Black Feminist Literary Criticism: ON INTERSECTIONS OF LEGAL AND LITERARY NARRATIVES
}

\begin{abstract}
Analyzing Karla FC Holloway's most recent book on literary criticism, Legal Fictions: Constituting Race, Composing Literature (2014), which explores the resonance between American literature and American jurisprudence, the paper makes a case for a new, viable trajectory within black feminist literary criticism. It argues that Holloway expands the line of black feminist (literary) scholars who have engaged in critical discussions of the construction(s) of race, offering new interpretations of black fictional works by way of engaging knowledge derived from or issues related to legal studies and/or by way of articulating legal criticism. In doing so, it demonstrates how black feminist critics continue to shape the landscape of both literary criticism and African American studies, creating a space for new conversations about and/or understandings of race in American society and culture.
\end{abstract}

Key words

Black feminist criticism; Karla FC Holloway; law; literature; race

\section{Introduction}

In 2006, within its section on "Theories and Methodologies," PMLA, the journal of the Modern Language Association of America, published ten essays by prominent feminist scholars addressing the issue of relevance of feminist criticism in the twenty-first century. Titled "Symposium: Feminist Criticism Today: In Memory of Nellie McKay," the selection of essays paradoxically failed to include a black feminist scholar's perspective on the issue under the scrutiny. ${ }^{1}$ 
Instead, it featured an interview with McKay, the late pioneering black feminist critic, recording her memories about the past life of black feminist literary criticism: the emergence of black literature in the academy, and the establishment of black women's literature in the canon.

As a possible response to the PMLA oversight, the following year, Signs: Journal of Women in Culture and Society published Farah Jasmine Griffin's essay "That the Mothers May Soar and the Daughters May Know Their Names: A Retrospective of Black Feminist Literary Criticism." In the essay, Griffin reviews the production of black feminist literary criticism and assesses its current state, noting that by the mid-1990s, it was "one of the most intellectually exciting and fruitful developments in American literary criticism" and that "[t]oday many scholars and critics continue to contribute to and expand the field" (2007: 484). Although she admits that black feminist criticism has experienced a backlash, ${ }^{2}$ she is clear that work informed by its tenets continues to be important for several reasons:

Readings that focus on the intersections of class, race, gender, sexuality, and nationality with an eye toward equality and justice are especially valuable today; a critique that emerges from those whose positionality has made them experience physical, psychic, and economic violence at the hands of the United States from within its borders provides a unique insight into the workings of this global, imperial power. (2007: 502)

In sum, as Griffin posits, black feminist criticism in the twenty-first century continues to offer a useful mode of analysis and a strategy of reading, having a potential to inspire and generate new scholarship, not only in the field of black feminist literary studies. ${ }^{3}$

In this paper, I will discuss one of the most recent examples of the new scholarship in the field of black literary studies, making a case for a new, viable trajectory within black feminist literary criticism. Analyzing Karla FC Holloway's book Legal Fictions: Constituting Race, Composing Literature (2014), which explores the resonance between American literature and American jurisprudence, I will argue that Holloway expands and transforms the line of black feminist (literary) scholars who have engaged in critical discussions of the construction(s) of race, offering interpretations of black fictional works by engaging knowledge derived from or issues related to legal studies and/or by articulating legal criticism. In doing so, I will demonstrate how black feminist critics continue to shape the landscape of both literary criticism and African American studies, creating a space for new conversations about and/or understandings of race, racial identity and personhood in American society and culture. ${ }^{4}$

\section{Legal Fictions}

In 2014, Karla FC Holloway published with Duke University Press her most recent book on literary criticism, Legal Fictions: Constituting Race, Composing 
Literature, in which she explores the intimate relationship between American literature and American jurisprudence. Arguing that there is a particular shared space between African American literary imagination and legal reasoning because of the history of legal boundedness of black people in the United States of America, she demonstrates in her book how U.S. black writers have grappled with (and in doing so, reframed) issues concerning both the law and racial identity. Drawing on knowledge derived from legal studies, she illuminates the ways in which U.S. law has constructed race and generated a national narrative that allowed for a critical exchangeability between citizenship and personhood.

Holloway traces the origins of her interest in the convergence of the literary with the legal to Toni Morrison's book on literary criticism, Playing in the Dark: Whiteness and the Literary Imagination (1992), in which Morrison argues that an Africanist presence in the United States has, inevitably, informed the fiction of white American authors:

Black slavery enriched the country's creative possibilities. [...] The result was a playground for the imagination. What rose up out of collective needs to allay internal fears and to rationalize external exploitation was an African Americanism - a fabricated brew of darkness, otherness, alarm and desire that is uniquely American. (1992: 38)

Pondering Morrison's insight, Holloway probes the foundational structure of African Americanism. As she explains her own line of thinking:

The one element that is missing from Morrison's deeply resonant consideration is what it was that could reliably undergird the structural component of that "fabricated brew"; what architecture would render the African Americanism — one that might engage its old continental history even as it set out its new continental cartographies? The playground does have an evident scaffold. Its foundations lie in the law. (1992: 109, emphasis in the text)

To follow Holloway's turn to the law, we must briefly consider African American literary history.

The origins of African American literature are often traced back to slave narratives, whose primary aim was not only to present the brutal reality of slavery and to inspire or support the abolitionist efforts, but also to prove that black people were fully human, as opposed to being the three fifths of all other persons as declared by the Constitution of the United States of America. ${ }^{5}$ As Holloway contends, "[o]ne might argue that African America's literary history paralleled African Americans' own history of personhood," which started with just a fraction of humanity (2014: x). Although, as she observes, the Fourteenth Amendment of 1868 granted black people the right to citizenship and restored their full personhood, the legal text did not overwrite the social act. In other words, despite their legally cognizable national citizenship, African Americans' social personhood 
was still being contested (2014: $\mathrm{x}$-xii). The dissonance between legal citizenship and black personhood (blackness embodied) can be traced, according to Holloway, from the era of enslavement to the era of first black presidency in the United States of America, ${ }^{6}$ and it has found its way into the fiction of African American writers - fiction which responds and testifies to the persistence of the constitutive legal boundedness of black identity in the United States.

Returning to Morrison's argument about the construction of literary blackness in the U.S. white imagination, Holloway argues that Playing in the Dark focuses on the fiction produced by white writers and "engages the ways in which their imaginations are (arguably legally) entailed by their inability to escape the race or their inability to "play' outside of the dark" (2014: 5, emphasis in the text). She goes on to suggest that "Morrison's idea of play" is tied to "a particular kind of rule boundedness that is like law" (2014: 5). Thus, her text can be read as "an inquiry into a persistently regulatory authority that is (perhaps perversely) dependent on a presumptive binary of literary lawlessness, a fugitivity that black texts 'play' against" (2014: 5). Picking up where, as she sees it, Morrison left off, Holloway turns her attention to texts produced not by U.S. white but black authors whose narratives "explore what happens when rules are contested, absent, or irregular" (2014: 5). These narratives, or rather, considerations of the aforementioned possibilities, are what Holloway identifies as "the contextual evidence of the outlaw consequence - the fugitivity in the dark" (2014: 5, emphases in the text).

For Holloway, American racial identity was, historically, "an imposed and prescriptive legalism that controlled access to legal citizenship," for African Americans first constitutionally described as three fifths of all other persons (2014: 10). Attached to citizenship were the rights to enter into a contract, to own property, and to bear witness (proffer evidence), which were fundamental in the framing of the Constitution (2014: 15). It is precisely these rights that Holloway uses as frames for her literary analyses to explore the law's contradictory constructions of race in fiction. Considering the issues of "personhood as property," "bodies as evidence," and "contract" as structures underlying African American texts, ${ }^{7}$ and using knowledge derived from legal studies, particularly as applicable to property, evidence and contract laws, to discuss their (d)e(m)ployment, she offers insightful readings of African American texts that seem to provide a rich record of property issues, evidentiary matters, and contracts. In doing so, she points to a new, interdisciplinary approach in black literary studies: reading critical legalisms.

\section{Law and Literature / Literature and Law}

In the last thirty years, the relationship between literature and law has become the subject of a newly emerging, interdisciplinary field: Law and Literature studies. ${ }^{8}$ The field can be broadly divided into two major areas-law in literature and law as literature. The former focuses on representations of legal issues in literary works; the latter explains legal texts by applying methods of literary interpreta- 
tion. ${ }^{9}$ Common to both is a keen interest in interpretation and narrative and the utility of literary texts and interpretative theory for the study of law. Indeed, law and literature studies has been designed for students of law - to help them acquire the skill of legal writing, to help them think about law in a different way, and to help them recognize the lived experience under systems of law in order to draw analogies between their own lives and legal problems (Ledwon 1996: ix-xii).

The significance of the literary narrative in law has also been acknowledged by critical race theorists who apply critical theory to the intersection of law, power, and race. For example, Patricia Williams attempted to create in her book The Alchemy of Race and Rights: The Diary of a Law Professor (1991), a genre of legal writing to "fill the gaps of traditional legal scholarship" by "exploit[ing] all sorts of literary devices, including parody, parable and poetry" (1991: 7-8). The value of stories in the field of black legal theory was also noted by the late African American legal scholar Jewel Amoah, who pointed out in "Narrative: The Road to Black Feminist Theory" (1997) that the practice of storytelling, or, what she calls Narrative, is deeply rooted in African American culture and that black women's stories have always addressed and theorized the quest for liberation and the importance of resistance, thus providing a sort of commentary on legal issues (1997: 84, 102). Interestingly, just like Holloway later, Amoah was inspired by Morrison's contemplation of African Americanism in white literary imagination, finding that " $[t]$ he contribution of the 'black presence' should not be interpreted as being limited to the national "literature" but rather "extended to apply to that area which is thought to be the most sacred ground of "white male views, genius and power': the law" (1997: 94).

Like legal scholars, African American scholars of literary and cultural studies have also noted the value of African American literature in providing insightful commentaries on legal issues. ${ }^{10}$ In African American Culture and Legal Discourse (2009), for example, Lovalerie King and Richard Schur point out that texts by African American authors have, historically, "exposed legal contradictions, [...] uncovered racist stereotypes hidden within legal doctrines, and [...] revealed how law has privileged and continues to implicitly favor the white majority" (2009: 4). ${ }^{11}$ This aspect of African American literature is also highlighted in Carlyle Van Thompson's Black Outlaws: Race, Law and Male Subjectivity in African American Literature and Culture (2010), which analyzes works by African American authors to expose the implications of legal restrictions in the lives of black males. In short, African American fiction has often been intertwined with legal discourse and through its literary devices it provided an insight into the complex relationship between American jurisprudence and race. In this light, Holloway's tapping into this rich reservoir represents a logical attempt to explicate, in a more comprehensive way, the ambiguous and often vexed relationship between American legal discourse and the racialized black subjectivity described in U.S. black fiction.

In this paper, I want to situate Holloway's project in a broader context to make a case for a viable trajectory within black feminist literary scholarship. To do so, I will analyze the work of two black feminist scholars, Hortense J. Spillers's 
groundbreaking essay “"Mama's Baby, Papa's Maybe': An American Grammar Book" (1987) and Saidiya V. Hartman's book Scenes of Subjection: Terror, Slavery, and Self-Making in Nineteenth-Century America (1997), both of which bring together literary and legal texts. Although neither Spillers's nor Hartman's primary interest lies in creating new literary interpretative theories (they employ literary texts as available tools to make larger arguments about black personhood/subjecthood in American culture and history, respectively), both Spillers and Hartman analyze issues related to legal studies to explore the law's ambiguous constructions of race in fiction by U.S. black authors, and thus provide, in their own ways, a theoretical foundation for Holloway, whose work can be seen as a continuation of the black feminist project.

\section{An American Grammar of Suffering}

Speaking across many disciplines, Spillers's essay “"Mama's Baby, Papa's Maybe': An American Grammar Book" reveals the epistemic, intellectual, and psychological violence that black people in general, and black women in particular, confront in their lives. Aimed at providing theoretical arsenal with which to address issues pertaining to their lives, the twenty-page essay begins with a list of epithets, labels, and stereotypes that American culture has used in reference to black women, fixing them in their respective places. Revealing how language is historically embedded and how the terminology used to describe black women performs an epistemological violence, Spillers turns her attention to the 1965 Moynihan Report, ${ }^{12}$ which blamed black women for the Negro "pathology," i.e., for dysfunctional black families out of line with the normative white American patriarchal structure.

Evoking the Lacanian Symbolic Order, Spillers points out how the Report exposes that "the 'Negro Family' has no Father to speak of," while "inscrib[ing] 'ethnicity' as a scene of negation" through the construction of the white/black binary opposition whose origins Spillers locates in African enslavement and the Middle Passage $(1987: 58,59)$. As Spillers argues, the transportation of the human cargo during the Middle Passage meant "a theft of the body - a willful and violent $[\ldots]$ severing of the captive body from its motive will," in which the black body became an object in the hands of [white] captors, [...] a territory of cultural and political maneuver, not at all gender related, gender-specific" (1987: 60, emphasis in the text). According to Spillers, "the respective [Lacanian] subject-positions of 'female' and 'male' adhere to no symbolic integrity" for blacks because they lose differentiation and validity within captivity through "the theft of the body" (1987: 58). Urging us to rethink these positions, as well as concepts of motherhood, fatherhood and family, which the symbolic order attaches to them, Spillers articulates the structural violence attached to genderless blackness in the United States by tracing what she calls an "American grammar" of suffering. This "grammar" represents a radical, politicized rewriting of the Lacanian 
symbolic order beginning with "rupture and a radically different kind of cultural continuation" (1987: 63).

In doing so, she turns her attention to slave narratives and autobiographies to examine what the Moynihan Report did not bring to light: American laws of inheritance and the American peculiarity of partus sequitur ventrem, a legal principle meaning that the slave child inherits the status of his or her mother, a principle incorporated in the U.S. legislation to ensure the bondage of black people.

According to Spillers, this patriarchal law, designed to protect property rights of slaveholders, causes an "inexorable difference" in the black community and produces a situation in which "the offspring of the female does not 'belong' to the Mother, nor is s/he 'related' to the 'owner,' though the latter 'possesses' it, and in the African-American instance, often fathered it" (1987: 73). In other words, the child "become[s], under the press of a patronymic, patrifocal, patrilineal, and patriarchal order, the man/woman on the boundary whose human and familial status, by the very nature of the case, had yet to be defined" (1987: 73). Spillers refers to this "enforced state of breach" as "another instance of vestibular cultural formation where 'kinship' loses meaning, since it can be invaded at any given and arbitrary moment by the property relations" (1987: 73, emphasis in the text). Within this context, she argues, "kin,' just as gender formation," has for African Americans "no decisive legal or social efficacy" (1987: 75).

Examining aspects of Frederick Douglass's Narrative of the Life (1845), Harriet Jacobs's Incidents in the Life of s Slave Girl (1861) and Malcolm El-Shabazz's Autobiography of Malcolm X(1966), Spillers exposes the social ambiguity, chaos and crisis to which black offspring are, historically, opened. Reading the narratives against the Louisiana, South Carolina, and Maryland slave codes, which place the word "slave" in the same context with non-human articles, Spillers concludes that the liberationist project of African Americans have been, historically, "to break apart [...] the laws of American behavior that make such syntax possible" and "to introduce a new semantic field/fold more appropriate to his/her own historic movement" (1987: 83). In this process, she finds, the aforementioned stories represent "narrative ambitions" or "intervening, intruding tale[s]" (1987: 83, emphasis in the text).

Although Holloway is not interested in psychoanalysis and does not acknowledge her debt to Spillers's essay, I would argue that Spillers's text foreshadows several issues that Holloway elaborates on in Legal Fictions. First, like Spillers, Holloway identifies a national narrative which marks black subjects and finds its origin story in slavery. Whereas Spillers traces the beginning of the story to the Middle Passage, during which occurred "the theft of the [black] body," i.e., an objectification of blacks leading to their subsequent legal codification as non-human articles (property), Holloway's point of departure becomes the formulation of the Constitution the United States of America, which declared black people three fifths of all other persons in the country, or in her words, a fraction of humanity. Both Spillers and Holloway identify these origins moments as fundamental in the construction of racial identity in the United States. Yet while Spillers chooses to 
approach the issue of the construction of racial identity and its effects from the psychological and semiotic points of view, Holloway, more than a quarter-of-acentury later, proceeds to consider the legal aspect of the matter.

In doing so, not unlike Spillers before her, Holloway notes the leak of the past into the present, both in terms of the (legal) treatment of black people whose "livelihood is refracted through a racial lens that has its history in the structure of enslavement" and in terms of "what lingered from a literary tradition that was deeply engaged with slavery, identity, and freedom [and law]" (qtd. in Leman 2014), that is, black fiction's continued interest in intervening. Also, it is Spillers's argument that despite the liberation of blacks, "dominant symbolic activity [...] remains grounded in the original metaphors of [black] captivity [...] murder [ing the black subjectivity] over and over again" (Spillers 1987: 63, emphasis mine) that finds resonance in Holloway's claim that black social personhood is still being contested and that these contestations have to do with the history of the legitimacy of black citizenship in the United States.

In the same way as does Spillers, Holloway acknowledges that language is crucial to the formulation of American racial identity, the fiction of the law as well as the fiction produced by U.S. authors. If Spillers, alluding to Faulkner's description of "the ancient subterrene atavistic fear," writes in 1987 that "sticks and bricks might break our bones, but words will most certainly kill us" (1987: 63 , emphasis in the text), highlighting the effects the psychological violence of evaluating on black people, Holloway traces that violence and black people's response to it in U.S. black literary fiction, arguing that both law and literature "depend on a critical intimacy with the ways and means of language" (2014: 6). In this respect, Spillers's brief but deft analyses of slave narratives, in which she discusses the connection between kinship and property, revealing chaos and crisis in the lives of blacks caused by American slave laws and laws of inheritance, become building blocks for Holloway's more elaborate and extensive analyses of other U.S. black texts.

Finally, and perhaps most importantly for my own thesis, Spillers's text, although more invested in cultural studies and semiotics rather than law, foreshadows Holloway's project in that it brings into focus not only the convergence of the legal and the literary through the discussions of laws (slave laws, property laws and laws of inheritance) in slave narratives, but also the continued link between law and the lives of African Americans. Spillers' very language, though not consciously derived from legal studies, addresses three distinct legal terms related to violence - theft, murder, and killing ${ }^{13}$ - that explicitly reveal a victim status of blacks, which the "narrative ambitions" she chooses to analyze document. The idea of violence attached to black life and the method of using narratives as means of documenting that violence links Spillers's text to Saidiya Hartman's book Scenes of Subjection: Terror, Slavery, and Self-Making in Nineteenth-Century America, another (unacknowledged) building block for Holloway. 


\section{The Legal Condition of Subjection}

A major scholarly contribution to historical, cultural, and literary studies, Scenes of Subjection explores racial subjugation during slavery and its aftermath. It opens with a radical reading of Frederick Douglass' Narrative, which positions the slave as simultaneously both subject and object. As Hartman argues:

The "terrible spectacle" that introduced Frederick Douglass to slavery was the beating of his Aunt Hester. [...] By locating this "horrible exhibition" in the first chapter of his 1845 Narrative of the Life of Frederick Douglass, Douglass establishes the centrality of violence to the making of the slave and identifies it as an original generative act equivalent to the statement "I was born." [...] [T] he terrible spectacle dramatizes the origin of the subject and demonstrates that to be a slave is to be under the brutal power and authority of another. (1997: 3)

The slave subjectivity is thus constituted as one whose major characteristic is that of submission and which is shaped by terror, for it is closely tied to violence that plays a central role in the formation of the enslaved - it gives birth to the slave as a violated object, legally defined as property.

Considering the transformation of property into man enabled by the abolition of slavery, Hartman points out a discontinuity between legal emancipation of slaves, which conferred on blacks the inalienable rights of man, and their substantial freedom. The "paradox of emancipation," according to Hartman, lies in "the coupling of coercion and contract, liberty and necessity, [and] equality and subjection," which helped maintain blacks' subjectivity with circumscribed humanity" (1997: 127). Arguing that racial slavery was never annulled but instead transformed into "another mode of servitude," in which the lives and liberties of black people were regulated and restricted "in the name of the public welfare and the health and prosperity of the population" (1997: 198), Hartman goes on to demonstrate how black people's humanity continued to be circumscribed after Reconstruction to uphold white privilege and preserve a racial order. Analyzing in detail those "entanglements of freedom and slavery" in legal cases as well as in American cultural production - literary texts, plantation diaries, freedmen's primers and slave performances - Hartman "examine[s] the role of rights in facilitating the relations of dominion" and "the new forms of bondage" and questions whether the rights of man and citizen as conceived in the American Constitution and law are indeed "realizable for all people or whether the appellation 'human' can be borne equally by all" (1997: 6). ${ }^{14}$ In doing so, examining the "varied and contested articulations of blackness in regard to issues of responsibility, will, liberty, contract, and sentiment," she revisits the founding narrative of the liberal subject and liberal individualism, revealing whiteness and manhood as "norms of liberal equality" (1997: 118). 
Just like Spillers before her (whom she credits and cites as one of her sources for the discussion of the management of female slaves' sexuality), Hartman uses black literary texts not to formulate a new critical theory of interpretation but to gain "a glimpse of black life during slavery and the postbellum period" (1997: 11), which would allow her to make a larger claim about racial subjugation during slavery and its aftermath. Her text, however, shares affinity with Holloway's project in several ways. First, in the same vein as Holloway would expose it later, Hartman takes note of the discrepancy between legal emancipation of blacks and their acquisition of full rights of man. Arguing that "[h]eld captive by the vestiges of the past, and cast into a legal condition of subjection - these features limn the circumstances of $[\ldots$ a] burdened subject no longer enslaved, but not yet free" (1997: 206), Hartman foreshadows Holloway's argument that black people are, historically, bound by law. Moreover, despite limiting her research to the nineteenth century, her words point to "a history of the present" as they summon up "the moment of potentiality between the no longer and the not yet," thus opening a space for Holloway to extend the argument into the twenty-first century (Hartman and Wilderson 2003: 192). As Hartman and Wilderson explain, "the articulation of the 'not yet free' is from the space of the twenty-first century, not the nineteenth, and that's the way it's supposed to carry - the same predicament, the same condition" (Hartman and Wilderson 2003: 192).

Second, like Holloway, to demonstrate her claims, Hartman uses black people's narratives, fictional as well as autobiographical, to locate and expose the complex and ambiguous descriptions of their shifting but always racialized and circumscribed subjectivity. But whereas Holloway celebrates the creative fugitivity of black U.S. writers who would explore the law's inconsistencies and play against the "presumptive binary of literary lawlessness," Hartman is concerned about the authenticity of the (re)construction of the subject disfigured by the scaffold of dominant (white) interests. Aware of the context in which they were produced and which, inevitably, shaped them, she reads the narratives "against the grain" of dominant discourse, yet recognizing their "political utility" and "ethical necessity" (1997: 14). ${ }^{15}$

Reading "against the grain" of dominant discourse, she also reads them in juxtaposition to legal documents, highlighting, very much like Holloway would later, their shared, albeit diverging, engagements with legal issues such as contract, property, and personhood. In part I of her book, Hartman examines these issues within the context of both the slave law and the common law, illuminating the legal mechanisms that sanctioned legitimate uses of slave property and its regulation as well as discipline to maintain white dominance and racial hierarchy. In doing so, she not only reveals how these mechanisms depended upon various methods of sexual control and domination ${ }^{16}$ but also the paradoxical status of the slave whose humanity (reasoning subjectivity) was recognized only in the context of criminal liability, as a way of projecting white culpability onto the enslaved (1997: 82).

In Part II, she critically interrogates the terms "will," "agency," "individuality" and "responsibility," examining them in relation to a rights-bearing black 
subjectivity and legalities attached to that discourse. In doing so, she reveals the law's ambiguities in defining and codifying black subjectivity and demonstrates how literary texts take notice of these ambiguities, exploring them from the perspective of the dispossessed. Reframing these ambiguities through the prism of the burdened black individuality, Hartman argues that the narratives critique the failures, omissions, and limitations of the law as they disclose the law's effects on black subjects endowed with full legal citizenship but not full rights of man. It is this argument that seems to resonate in Holloway's claim that fiction by the U.S. black writers exposes race as a "constructed legal fiction" (2014: 6), inconsistent with both embodied blackness and "America's shifting social judgments on questions of rights that the law has arguably settled" or tried to provide a framework for their resolution (2014: 22).

For Hartman, as well as for Holloway, the details in legal narratives (the law) and in fictional narratives by black U.S. writers provide a rich documentation of "the legally bound hypervisibility of race" in America (2014: 124). But while for Hartman, whose primary objective is to illuminate "the entanglements of slavery and freedom" in American cultural production, black literature is just one of many sources to scrutinize (1997: 14), for Holloway, black fiction is the record of "legal traces" that "exist, matter, and instantiate the biosociality of a persistent racial legibility mapped within the intersectionalities of identitarian fictions of law" (2014: 123, emphasis mine). In other words, black literature, for Holloway, becomes a "complex, nationally necessary and precious terrain" that, engaging the legal, recasts the national narrative of race (itself a fiction) and serves as "evidence of the 'novelization' or 'novelizing protocols' of a collective imagery that exists in tandem with legal rule" $(2014: 125,123)$.

\section{Conclusion}

Despite the shared interdisciplinary focus of Spillers's, Hartman's and Holloway's texts and their various intersecting points, only Holloway's Legal Fictions stands out as a project contributing primarily to literary studies as opposed to one conceived as a work of cultural history or historiography, terms more fitting to describe Spillers's and Hartman's works. ${ }^{17}$ Holloway opens the book with a reference to African American letters and literary kinship, locating her arguments in a debate about "a persistent anxiety of [European] influence" in black literature and black theorists" search "for a critically distinct tropes ... that would give [the literature] critical evidence of an evolutionary formulation" (2014: x). In other words, Holloway's situates her own approach in reference to the origins and the tradition of black U.S. literature. Without essentializing that tradition, ${ }^{18}$ Holloway makes two important claims about it: U.S. black literature is bound by law; and the law can serve as a new lens through which to approach its texts.

Suggesting we approach the texts as narratives structured by legal issues, Holloway points to a new approach in black feminist criticism, which she refers to 
as reading critical legalisms, an approach distinct from the work of Law and Literature studies and legal studies scholars in that it does not privilege law over literature. By bringing reading critical legalisms into the landscape of both literary criticism and African American studies, she creates a space for new conversations about and/or understandings of racial identity and personhood, and expands (while transforming it) the line of black feminist (literary) scholars who have engaged in critical discussions of the construction(s) of race by way of employing knowledge derived from or issues related to legal studies, and/or by way of articulating legal criticism. Within this new approach, Holloway further suggests an untrodden path to take. Coming back full circle to Toni Morrison's consideration of the construction of blackness in white U.S. writers' imagination, in Epilogue to Legal Fictions, she stretches the boundaries of the literary terrain to include texts by white non-U.S. writers in order to "acknowledge the ways in which diasporic imaginations are [also] subject to contingent racialized fictions" (2014: 110).

Holloway's theory of reading critical legalisms also engages in the conversation with black scholars about the future of African American literature, providing a commentary on Kenneth Warren's provocative thesis published in What Was African American Literature? (2011). Arguing that what we now call "African American literature" ended with the legal abolition of segregation because it was a literature written in response to the Jim Crow regime, Warren proclaimed African American literature a project of the past, although acknowledging that post-segregation writers "have often remained oriented by the project of Negro literature as if was defined by responses to Jim Crow" (2011: 5). Rejecting this perspective, Holloway writes:

[Legal Fictions'] notice of the critical and persistent intersectionality of objectified racialisms does not convey a judgment regarding the desirability of this notice, but it is certainly a clarification for those who would imagine that race(d) literatures ended along with the era of de facto or de jure segregations. Reading critical legalisms into U.S. literary histories imagines these outcomes quite differently. (2014: 124, emphasis mine)

Challenging Warren's thesis that African American literature "would seem to be at an end [...] because the boundary creating [its] distinctiveness has eroded" (Warren 2011: 8), by redirecting our attention to black literature's legal origins, Holloway's voice contributes to an important current debate that involves more than just the question of African American literary tradition. As Marlon B. Ross reminds us, what is at stake here could very well be the future of the whole discipline of African American studies. ${ }^{19}$ 


\section{Notes}

$1 \quad$ See "Symposium: Feminist Criticism Today: In Memory of Nellie McKay." PMLA 121. 5 (2006): 1678-1741. As is clear from the title of the symposium and the section in which the essays were placed, the terms theory and criticism are often used interchangeably in literary studies. While I use primarily the term criticism in this essay, I also use it to refer to both criticism and theory.

This backlash is, according to Griffin, due to "critiques that fault the field for being a bastion of identity politics and essentialism" (2007: 484), which also target African American studies. Similar backlash is also felt in women's studies and feminist studies in general (hence the $P M L A$ effort to address the issue). Indeed, since the publication of Griffin's essay, there have been several exciting developments in the field of black feminist criticism. Examples of the most recent scholarship in literary studies include Henderson (2014), Holloway (2014), Washington (2014), Lordi (2013) and Shockley (2011). In this paper, I use the terms black and African American interchangeably. This is a reference to the Three-Fifths Compromise of 1787, which was a compromise to diminish the political power of Southern States. The issue was thus also one of national political power.

Holloway reads President Barack Obama's first claim to his office as a claim to legal personhood since the spoken challenge to his legitimate occupancy of the office involved a property as well as a citizenship claim - he had to proffer a birth certificate as evidence of his rightful claim to a federally viable citizenship (2014: xiii).

Holloway employs various texts ranging from slave narratives to contemporary fiction, arguing that "nearly all African American fiction inevitably engages some dimension of the legal" (2014: 17).

Although the beginning of the field can be traced back to James Boyd White's publication The Legal Imagination (Chicago: The University of Chicago Press, 1973), as a discipline with institutional support Law and Literature does not emerge until the 1980s.

There are other classifications. For example, Anthony Julius (1999: xiii) distinguishes four areas: the law of literature, law as literature, law in literature, and legal and literary hermeneutics, while Kieran Dolin (2007: 10-11) identifies nine "structures and associations," adding to the mix, for example, the use of theatricality and spectacle in the creation of legal authority, the cultural and political consequences of new technologies of communication, and the effects of social ideologies such as race and gender in legal language.

There are also white American literary scholars who have noticed and commented on the value of African American literature in providing insightful commentaries on legal issues. See, for example, Hendrick (2012), Suggs (2010), and Crane (2002).

The collection contains an essay by Karla FC Holloway, "W. E. B. DuBois and the Right to Privacy," which, I believe, was an early bird indicative of Holloway's project that would eventually develop into Legal Fictions.

The Moynihan Report, or, The Negro Family: The Case for National Action, was a document written by the U.S. Senator Daniel Patrick Moynihan, addressing the issue of poverty among African Americans. Pointing out the relative absence of nuclear-family units in black community, it blamed single-mothers for hindering black children's achievements. A theft is a criminal offence that has to do with property laws; killing and murder are considered to be acts of homicide and violations of criminal law. Interestingly, Spillers mentions the word "criminal" in relation to the "thefts of the body," considering them "high crimes against the flesh" (1987: 61), thus making clear that law is the proper context in which to discuss lives of black subjects. Hartman's project is often seen in line with Afro-Pessimism, a term coined by Frank B. Wilderson, III, whose major tenet is that blackness is antagonistic to humanity. This is, undoubtedly, due to the fact that her primary interest is in history (as opposed to 
literary studies) and that she limits her discussion of literary texts to the $19^{\text {th }}$ century slave narratives and black people's testimonies collected in the 1930s as part of the Federal Writers' Project of the Works Progress Administration. The latter, as she points out in her book, were conducted and recorded by white people who could have been sons and daughters of former slave owners. Holloway, on the other hand, uses the fiction of the late twentieth and twentyfirst centuries and her primary interest is in literary studies.

These, according to Hartman, included "anti-miscegenation statues, rape laws that made the rape of white woman by black men a capital offense, the sanctioning of sexual violence against slave women by virtue of the law's calculation of negligible injury, the negation of kinship, and the commercial vitiation of motherhood as a means for the reproduction and conveyance of property and black subordination" (1997: 84). Hartman is particularly interested in the management of female slaves' sexuality as manifested in case laws.

17 Interestingly, while the Library of Congress catalogue tag on the copyright page indicates the following areas: 1. American literature-African American authors-History and criticism. 2. African Americans - Legal status, laws, etc.-History. 3. Race discrimination-Law and legislation-United States - History. 4. Race in literature, on its back cover, Legal Fictions has been tagged as Law and Literature, and African American studies. I see this as a marketing move at a time when literary studies is experiencing decline in readership and Law and Literature studies is gaining more attention. Holloway (in Leman 2014) herself imagines her audience to be both literary and legal scholars, citing literary first. For more reasons as to why the book should be read as a new text of black literary studies, see the end of my essay. This is evident in her use of the plural form: U.S. black literatures.

In his review of Kenneth Warren's book, Marlon B. Ross defines the stakes clearly. Given the fact that literature has always been a pillar of African American studies, whose worth as an academic (inter)discipline has always been subject to debate, declaring the death of its very subject could bring about serious consequences, among them defunding. See Ross (2012).

\section{Acknowledgement}

This paper is an outcome of the Czech Science Society grant (GAČR) No. 1326975S, "Black Feminist Literary Criticism."

\section{References}

Amoah, Jewel (1997) "Narrative: The Road to Black Feminist Theory." Berkeley Women's Law Journal 12 (1): 84-102.

Crane, Gregg (2002) Race, Citizenship and Law in American Literature. New York: Cambridge University Press.

Dolin, Kieran (2007) A Critical Introduction to Law and Literature. New York: Cambridge University Press.

Douglass, Frederick (1845) Narative of the Life of Frederick Douglass, an American Slave. Written by Himself. Boson: Anti-Slavery Office.

El-Shabazz, Malcolm (1966) Autobiography of Malcolm X. New York City: Grove Press.

Griffin, Farah Jasmine (2007) "That the Mothers May Soar and the Daughters May Know Their Names: A Retrospective of Black Feminist Literary Criticism." Signs: Journal of Women in Culture and Society 32 (2): 483-507.

Hartman, Saidiya (1997) Scenes of Subjection: Terror, Slavery, and Self-Making in NineteenthCentury America. New York and Oxford: Oxford University Press. 
Hartman, Saidiya V. and Frank B. Wilderson, III (2003) "The Position of the Unthought." Qui Parle 13 (2): 283-201.

Henderson, Mae G. (2014) Speaking in Tongues and Dancing Diaspora: Black Women Writing and Performing. New York: Oxford University Press.

Hendrick, Veronica C. (2012) Servants, Slaves and Savages: Reflections of Law in American Literature. Durham: Carolina Academic Press.

Holloway, Karla FC (2014) Legal Fictions: Constituting Race, Composing Literature. Durham: Duke University Press.

Jacobs, Harriet (1861) Incidents in the Life of a Slave Girl. Written by Herself. Boston.

Julius, Anthony (1999) "Introduction." In: Freeman, Michael and Andrew D. E. Lewis (eds.) Law and Literature: Current Legal Issues, vol. 2. Oxford: Oxford University Press, xi-xxv.

King, Lovalerie and Richard Schur, eds. (2009) African American Culture and Legal Discourse. Basingstoke: Palgrave McMillan.

Ledwon, Lenora, ed. (1996) Law and Literature: Text and Theory. New York and London: Garland Publishers.

Leman, Hope (2014) "Interview with Karla F.C. Holloway, Author of 'Legal Fictions: Constituting Race, Composing Literature." Critical Margins. Available at http:// criticalmargins. com/2014/03/05/interview-karla-f-c-holloway/. Accessed on April 12, 2015.

Lordi, Emily (2013) Black Resonances: Iconic Blues Singers and African American Literature. New Brunswick: Rutgers University Press.

Morrison, Toni (1992) Playing in the Dark: Whiteness and the Literary Imagination. New York: Vintage Books.

Ross, Marlon B. (2012) "Kenneth W. Warren's What Was African American Literature?: A Review Essay." Callaloo 35 (3): 604-612.

Shockley, Evie (2011) Renegade Politics: Black Aesthetics and Formal Innovation in African American Poetry. Iowa: University of Iowa Press.

Spillers, Hortense ([1987]2000) “"Mama's Baby, Papa's Maybe': An American Grammar Book." In: James, Joy and T. Denean Sharpley-Whiting (eds.) The Black Feminist Reader. Malden and Oxford: Blackwell Publishers, 57-87.

Suggs, Jon-Christian (2010) Whispered Consolations: Law and Narrative in African American Life. Ann Arbor: University of Michigan Press.

Van Thompson, Carlyle (2010) Black Outlaws: Race, Law and Male Subjectivity in African American Literature and Culture. New York: Peter Lang Publishers.

Warren, Kenneth (2011) What Was African American Literature? Cambridge, MA: Harvard University Press.

Washington, Mary Helen (2014) The Other Black List: The African American Literary and Cultural Left of the 1950s. New York: Columbia University Press.

Williams, Patricia (1991) The Alchemy of Race and Rights. Cambridge, MA: Harvard University Press.

Karla Kovaloví is Assistant Professor of English at the University of Ostrava, Ostrava, Czech Republic. She is the author of To Live Fully, Here and Now: The Healing Vision in the Works of Alice Walker (Lexington: Rowman \& Littlefield, 2007) and the editor of Černošská feministická literární kritika: Výbor z teoretických statí afroamerických kritiček (Praha: SLON, 2014) and Black Feminist Literary Criticism: Past and Present (Frankfurt: Peter Lang, 2016). She has published articles about U.S. black literature in both Czech and international journals.

Address: Karla Kovalová, Department of English, Reální 5, 70100 Ostrava, Czech Republic. [email: Karla.Kovalova@osu.cz] 
